\title{
Effects of Gamma-Irradiation on Microbial Contamination and on Histological Changes of Muscle in Poecilia reticulata
}

\author{
Katarína Beňová ${ }^{1}$, Petr Dvořák², Miloš Halán ${ }^{1}$, Zuzana Kaleničová1, \\ Hedviga Sehnálková3 ${ }^{3}$ Viera Cigánková ${ }^{1}$
}

${ }^{1}$ University of Veterinary Medicine, Košice, Slovak Republic

${ }^{2}$ Faculty of Veterinary Hygiene and Ecology, University of Veterinary and Pharmaceutical Sciences Brno, Czech Republic

${ }^{3}$ Institute of Medical and Clinical Microbiology, FNLP Košice, Slovak Republic

Received May 6, 2008

Accepted November 12, 2008

\begin{abstract}
This study describes the effect of gamma-irradiation on the microbial skin and organ contamination and on the histological changes of fish skeletal musculature. The aquarium fish Poecilia reticulata were exposed to the radiation effect of ${ }^{60} \mathrm{Co}$ at the doses of 20 and $30 \mathrm{~Gy}(11.36 \mathrm{~Gy} / \mathrm{min})$. Frequent intravital haemorrhages were observed from day 8 after the exposure. A general long-term body fading appeared from day 10 to day 30 of the experiment. Microbiological and histological examinations were done on days 7, 14, 21 and 28. Individual muscle cells were bound together into fascicles surrounded by connective tissue. No significant morphological changes were observed on skeletal muscle cells, except for more watery connective tissue.

The presence of Escherichia coli and Aeromonas hydrophila was proved in the body surface samples and in aquarium water based on the microbiological test. A moderate increase of the number of $E$. coli and A. hydrophila was observed in the intestines in both exposed groups (20 and $30 \mathrm{~Gy}$ ) depending on the time that elapsed from the exposure (from $1 \times 10^{1}$ to $6 \times 10^{3}$ $\mathrm{CFU})$. However, the heart, liver and musculature remained sterile. No microbial contamination of musculature was found for the intravital ionizing radiation dose of 30 Gy even for the single specimen killed on day 28 from the exposure.
\end{abstract}

Ionizing radiation, foodstuff safety, radiation sickness, model fish

An extensive introduction of nuclear energy in practical fish culture is called alternative radiation protective methods of fish health. For this reason, detailed knowledge of biological effects of ionizing radiation for pathogenesis of radiation sickness is very important (Albaum 1960; Beňová et al. 2006). At present, abundant data on different aspects of ionizing radiation and its impacts on the living organisms have been gathered (Flory and Neuhaus 1976; Falis et al. 2004). However, a unified theory of the biological effects of this mechanism on the organisms has not been published yet. In many studies, little attention has been paid to the serious biological effects such as impaired immunity and possible auto-infections in relation to food safety (Puzová et al. 1962; Beňová et al. 2002).

Unlike in mammals and birds (Kunstýř and Pospíšil 1962; Kalina et al. 1994), the gamma-irradiation effect in fish has been investigated in a relatively small group so far. However, the meat of fish treated by gamma radiation can represent a remarkable risk for the consumers. Additionally to non-pathogenic organisms, fish and other water organisms may contain microorganisms that have a negative effect on human health. Especially, Aeromonas hydrophila, Plesiomonas shigelloides, Vibrio cholerae, Vibrio parahaemolyticus and Vibrio vulnificus (Pipová et al. 2006) are the most important pathogens.

Higher radiation doses may cause the gastrointestinal syndrome that leads to defects of the intestinal mucosa barrier with successive contamination of musculature. 
From the experimental point of view, aquarium fish such as Poecilia reticulata and Danio rerio present a suitable experimental model to study the above-mentioned questions (Lešník and Jurčina 1994).

\section{Materials and Methods}

We used Poecilia reticulata from our own laboratory breeding colony. The body weight of the fish varied from $4 \mathrm{~g}$ (males) to $6 \mathrm{~g}$ (females). The breeding was maintained under constant ambient conditions, i.e. water with a temperature of $24^{\circ} \mathrm{C}, \mathrm{Ca}+\mathrm{Mg}$ components of $0.7 \mathrm{mmol} / \mathrm{l}, \mathrm{pH}$-factor of 7.04, artificial aeration, water filtration, photo-period of 12:12 h L:D (OECD 1992).

The fish were fed living organisms (A. franciscana) and flaky and granular fodder (AQUA EXOTIC, Kapušany, Slovakia). Fish specimens used for the experiments were randomly selected, divided into groups and kept under standardized conditions and fed only the granular highly nutritious fodder specified for this species (Easy fish). Two groups of fish were formed for the test of two gamma radiation doses at the beginning of the experiment. There were thirty fish specimens (a total of 90 specimens in three replicates) in each experimental group. Twentylitre aquaria were used to keep the fish of both groups during the experiment.

The fish were exposed to the gamma-radiation doses of 20 and $30 \mathrm{~Gy}$ using Chisostat $\left({ }^{60} \mathrm{Co}\right.$ source and the dose rate of $11.36 \mathrm{~Gy} / \mathrm{min}$ ). They were exposed to radiation in Petri dishes in aquarium water, with the water column of $1 \mathrm{~cm}$. The control samples were sham-exposed, i.e. the control samples were subjected to the complete procedure except for gamma radiation exposure.

For 30 days from the exposure every day we observed and recorded data on all the changes manifested on the body surface. On days 7, 14, 21 and 28 after the radiation exposure, we took sterile samples of the intestine, heart, liver and muscle from six fish specimens $(6 \times 4+6$ control $)$, and performed microbiological tests. The body surface samples and water samples also were subjected to the microbiological test. The results were completed with the histological examination of muscle.

The samples intended for histological examinations were processed using standard methods. All pieces of fish were fixed in 3\% neutral formol and covered with paraffin. The histological sections with a thickness of $7 \mu \mathrm{m}$ were stained with haematoxylin-eosin. They were viewed by means of the JENAMED optical microscope with a micro-camera.

Blood agar, McConkey agar, End agar and Brain Heart Infusion Broth substrate (Mikula et al. 1997) were used in the microbiological tests. The samples were shaken out and diluted in saline by the quantitative method for determining the number of bacteria in $1 \mathrm{ml}$. Specific kinds of bacteria were detected by commercial testing products (ENTEROtest 16, LACHEMA Brno and NEFERMtest 24).

\section{Results}

Haemorrhages were observed on the exposed fish surface based on the changes that were manifested during days 8 to 12 after exposure in both experimental groups. The most significant haemorrhages were observed in the area of liver and the lower part of the body cavity (Plate XIII, Fig. 1). Fading of the body colouration was detected from day 10 and it persisted till day 30 from the exposure day. We observed a reduced food intake in both experimental groups.

Microbiological investigations of the body surface sample and the aquarium water sample yielded the same results. E. coli and A. hydrophila were present in both cases.

A moderate increase of the number of $E$. coli and $A$. hydrophila (Table 1) was observed in the intestine in both exposed groups (20 and 30 Gy). Heart, liver and muscles remained sterile in all the monitored periods after the exposure.

Skeletal muscle cells (Plate XIII, Fig. 2) were not damaged, and additionally their surface was covered by a continuous membrane - sarcolemma. In the sarcoplasm they contained multiple oval nuclei, located peripherally or centrally within the cell. When viewed in the longitudinal section, transverse striations were present as alternating light

Table 1. The changes of microflora (CFU) in the fish intestine depending on the exposure time

\begin{tabular}{|c|c|c|c|c|c|c|c|c|c|c|}
\hline & \multirow[t]{2}{*}{ Control } & \multicolumn{2}{|c|}{ Day 7} & \multicolumn{2}{|c|}{ Day 14} & \multicolumn{2}{|c|}{ Day 21} & \multicolumn{2}{|c|}{ Day 28} \\
\hline & & & $20 \mathrm{~Gy}$ & $30 \mathrm{~Gy}$ & $20 \mathrm{~Gy}$ & $30 \mathrm{~Gy}$ & $20 \mathrm{~Gy}$ & $30 \mathrm{~Gy}$ & 20 Gy & $30 \mathrm{~Gy}$ \\
\hline \multirow[t]{2}{*}{ Intestine } & E. coli in CFU.g ${ }^{-1}$ & $2 \times 10^{1}$ & $1 \times 10^{1}$ & $2 \times 10^{3}$ & $3 \times 10^{3}$ & $2 \times 10^{3}$ & $3 \times 10^{3}$ & $3 \times 10^{3}$ & $5 \times 10^{3}$ & $3 \times 10^{3}$ \\
\hline & A. hydrophila in $\mathrm{CFU} \cdot \mathrm{g}^{-1}$ & $3 \times 10^{1}$ & $3 \times 10^{1}$ & $3 \times 10^{1}$ & $2 \times 10^{3}$ & $1 \times 10^{3}$ & $3 \times 10^{3}$ & $4 \times 10^{3}$ & $6 \times 10^{3}$ & $5 \times 10^{3}$ \\
\hline
\end{tabular}


and dark bands. Each muscle cell contained myofibrils composed of thick and thin myofilaments, responsible for contraction. Thick and thin myofilaments overlapped in darker A band (anisotropic), whereas only thin myofilaments were present in the lighter I band (isotropic). Individual muscle cells were bound together into fascicles surrounded by connective tissue. No significant morphological changes were observed on the skeletal musculature, only the tissue seemed more watery than in the control specimens.

\section{Discussion}

In general, as a consequence of high radiosensitivity of the dividing enterocytes, their production in crypts is interrupted; and their movement to the villus peak and replacement of necrotic enterocytes is observed. Complete recovery process of the intestinal epithelium, and moreover, the intestinal mucosa loses its functional capability. From the clinical point of view, this status is characterized by diarrhoea, nausea and successive cachexia. Damage of the intestinal barrier is typical during irradiation sickness in mammals and it related to high radiosensitivity of endothelial cells (Procházka and Dvořák 2002; Beňová et al. 2002).

In our study, an increase of blood capillary penetrability led to the development of haemorrhagic diathesis which was manifested by haemorrhage in different parts of the body of the monitored pieces of fish. Haemorrhages were similar to the changes described by Hršel (1950) as inflammation processes on the skin of the exposed pieces of fish. The body colour fading often occurs in fish during changes of life conditions. This change of body colour is usually of only short-term nature (Samochvalovova 1935; Hršel 1950). In our experiment, the fading persisted approximately from day 10 till the completion of the experiment, that is, 30 days after the exposure.

Lack of appetite observed in our experiment in Poecilia reticulata exposed to X-rays was similar to that described in mammals and birds after exposure as reported by Seidelová (1986).

Penetration of the existing bacteria commonly present in the digestive tract of the exposed organism through the mucosa and the damaged blood capillaries of the intestinal wall into the blood circulation under physiological conditions was described in mammals. The found bacteria penetrate other organs and skeletal muscles through blood (Kunstýr and Pospíśil 1962; Puzová et al. 1962). In our trial, a moderate increase of the number of bacteria in the digestive tract was observed in the monitored fish. Organs and musculature remained sterile.

Microflora of the living fish depends on the microbial water contamination in which the individuals live (Frazier 1967). The following are the most often occurring genera: Alcaligenes, Acinetobacter, Bacillus, Enterobacteriaceae, Flavobacterium, Pseudomonas and Vibrio. Besides non-pathogenic organisms, fish and water animals may contain even microorganisms that can endanger human health. Of the most important pathogens we can mention the following: Aeromonas hydrophila, Plesiomonas shigelloides, Vibrio cholerae, Vibrio parahaemolyticus and Vibrio vulnificus (Pipová et al. 2006).

Frazier (1967), Grieger and Vařejka (1991) found that the number of microorganisms on the fish surface ranged from hundreds to many million per square centimetre. The number of microorganisms in the digestive tract ranged from $10^{3}$ to $10^{8} \mathrm{CFU} \cdot \mathrm{g}^{-1}$. The total numbers of microorganisms observed in fish muscle were from 0 to $10^{3} \mathrm{CFU} \cdot \mathrm{g}^{-1}$, which corresponds to our results. The great differences in the species spectra and number of microorganisms in fish skin and fish muscles led us to the conclusion that the fish skin (when not damaged) formed an effective barrier.

We did not observe any significant morphological changes in fish musculature. The changes on skin due to the exposure did not damage the barrier, and the musculature was 
contaminated neither by the microorganisms present in the aquarium water nor by autoinfection by the bacteria present in the digestive tract. Aeromonas bacteria are ubiquitous suspected pathogenic organisms of the aquarium fish. They induce a pathological response particularly under unsuitable living conditions. However, the symptoms of such infections are different from those resulting from radiation sickness. The infection of $P$. reticulata was proved in the grey spots on skin, resulting in the erythema symptom with protrusions of the affected zones above the skin surface. This process was best illustrated in P. reticulata by Bassleer (2003). However, the observed erythema was not of the haemorrhagic character considered as a symptom of radiation sickness. No other changes of skin or gills were observed.

Alternative model systems are used in biomedical research (Dvořák and Beňová 2002; Sklenář et al. 2006; Nováková et al. 2007) in order to protect higher vertebrates. Our experiments have not proved any microbial contamination of fish musculature even 28 days after the intravital exposure of specimens to the ionizing radiation dose of $30 \mathrm{~Gy}$.

\section{Vplyv žiarenia gama na mikrobiálnu kontamináciu a na histologické zmeny svaloviny Poecilia reticulata}

Táto práca popisuje účinok žiarenia gama na mikrobiálnu kontamináciu kože a orgánov a na histologické zmeny kostrovej svaloviny ryb. Akvarijné ryby Poecilia reticulata boli vystavené účinkom žiarenia ${ }^{60} \mathrm{Co}$ v dávkach 20 a 30 Gy (11,36 Gy/min). Intravitálne boli od 8. dňa po ožiarení pozorované rozsiahle krvácaniny. Celkové vyblednutie tela sa prejavilo dlhodobo 10. - 30. deň experimentu. Na 7., 14., 21. a 28. deň bolo urobené mikrobiologické a histologické vyšetrenie. Makroskopicky bola pozorovaná vodnatejšia svalovina. Došlo $\mathrm{k}$ intenzívnejšej väzbe vody $\mathrm{v}$ riedkom väzive, čím boli svalové vlákna od seba viac oddialené. Mikrobiologickým vyšetrením steru z povrchu tela a akváriovej vody bola preukázaná prítomnost' E. coli a Aeromonas hydrophila. V čreve rýb oboch ožiarených skupín (20 a $30 \mathrm{~Gy}$ ) došlo k miernemu zvýšeniu počtu $E$. coli a $A$. hydrophila v závislosti na dobe od ožiarenia (od $1.10^{1}$ po $\left.6.10^{3} \mathrm{CFU} \cdot \mathrm{g}^{-1}\right)$. Srdce, pečeň a svalovina však boli sterilné. V tomto pokuse nebola preukázaná mikrobiálna kontaminácia svaloviny intravitálnou dávkou ionizujúceho žiarenia 30 Gy ani u rýb usmrtených 28 dní po ožiarení.

\section{Acknowledgement}

The study was funded by the grant No. VEGA 1/0423/08 and No. MSM6215712402 of the Ministry of Education, Youth and Sports of the Czech Republic.

\section{References}

Albaum HG 1960: Serum enzymes following whole-body radiation in the rabbit. Radiat Res 12:186-194

Bassleer, G 2003: The new illustrated guide to fish diseases in ornamental tropical and pond fish. Bassleer Biofish Westmeerbeek, Belgium, $232 \mathrm{p}$.

Beňová K, Falis M, Toropila M, Sehnálková H, Pastvová L 2002: Influence of single $\gamma$-irradiation on rat microflora. Folia Microbiol 47: 461-462

Beňová K, Cigánková V, Falis M, Šmajda B 2006: Clinical symptoms and histological changes in Poecilia reticulata following gamma-rays irradiation. Acta Vet Brno 75: 557-560

Dvořák P, Beňová K 2002: The investigation of interactions of low doses of ionizing radiation and risk factors by means of Artemia salina biotest. Folia Vet 46: 195-197

Falis M, Beňová K, Toropila M, Sesztáková E, Legáth J 2004: Changes in the activity of selected adaptive enzymes in chicken liver after single gamma irradiation. Bull Vet Inst Puławy 48:503-506

Flory W, Neuhaus OW 1976: Induced transport of amino acids in rat liver after whole-body irradiation. Radiat Res 68:138-147

Frazier WC 1967: Food microbiology. $2^{\text {nd }}$ ed. McGraw-Hill Book Co., New York, 537 p.

Grieger C, Vařejka F 1991: Microbiology of foodstuff of animal origin (Mikrobiológia požívatín živočíšneho pôvodu) (In Slovak). Príroda, Bratislava, 288 p.

Hršel I 1950: The Effect of X-rays on spermatogenesis of Lebistes reticulatus. Univerzitní knihovna Praha, 134 p. 
Lešník F, Jurčina A 1994: Model system of fishes. Veterinářství 2: 210-211

OECD Guideline for testing of chemicals. Adopted by the Council on $17^{\text {th }}$ July 1992. Fish, acute toxicity test, 9 p.

Kalina I, Konečná H, Némethová G, Račeková N 1994: Adaptive response to ionizing radiation in normal and aneuploid human lymphocytes. Folia Biol-Prague 40: 119-123

Kunstýr I, Pospíšil J 1962: Penetration of Serratia marcescens from the intestine into the organism of irradiated dogs. Folia Microbiol 7: 83-87

Mikula I, Pilipčinec E, Tkáčik J, Pistl J, Holoda E 1997: Veterinary microbiology and immunology. Príroda, Bratislava, $205 \mathrm{p}$.

Nováková J, Daňová D, Strišková K, Hromada R, Mičková H, Rabišková M 2007: Zinc and cadmium toxicity using a biotest with Artemia franciscana. Acta Vet Brno 76: 635-642

Pipová M, Buchtová H, Cabadaj R, Gima J, Hanzel S, Iglovská N, Kantíková M, Kohút J, Košuth P, Kozák A, Nagy J, Pliešovský J, Rajský D, Sokol J, Steinhauserová I, Večerek V 2006: Hygiene and technology of freshwater and sea fish manufacturing (In Slovak). UVL Košice, VFU Brno, 417 p.

Puzová H, Szabová K, Čerman J, Puza A, Kunštadt E, Zaduban M 1962: The problem of autoinfection after total body lethal irradiation of dogs with sup ${ }^{60} \mathrm{Co}$. Folia Biol-Prague 8: 298-308

Procházka Z, Dvořák P 2002: Veterinary radiobiology and radiation hygiene (In Czech). University of Veterinary and Pharmaceutical Sciences, Brno, 125 p.

Samochvalovova GW 1935: Effect of X-rays on fishes. Biol J 7: 1023-1033

Seidelová A 1986: Lethal effect of X-rays on penguin fish varieties Poecilia reticulata Peters and Brachydanio rerio. Radiobiologia 6: 820-822

Sklenář Z, Dvořák P, Beňová K 2006: Utilization of Artemia salina test for study of toxicological effects of cyclin-dependent kinases (In Czech). Klin Farmakol Farm 20: 62-65 
Plate XIII

Beňová K. et al.: Effects of Gamma- ... pp. 173-177

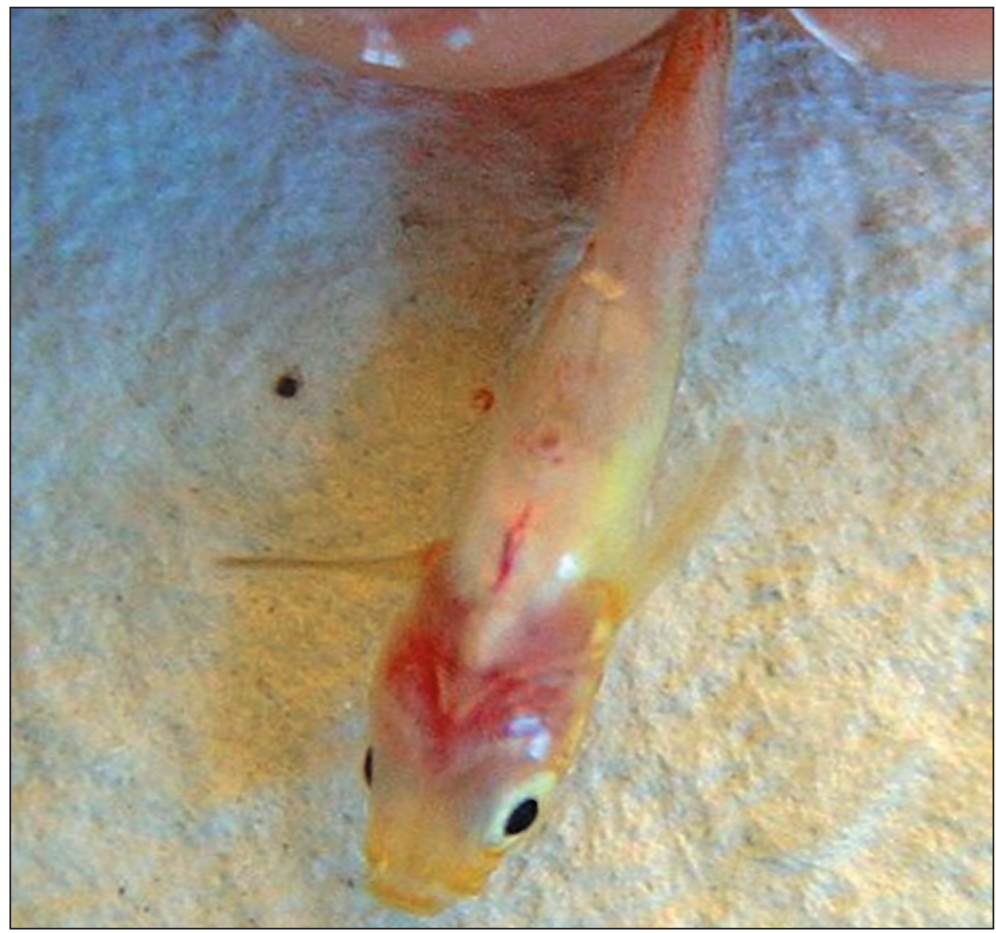

Fig. 1. Haemorrhages on the fish body. A view of the abdominal part of the body.

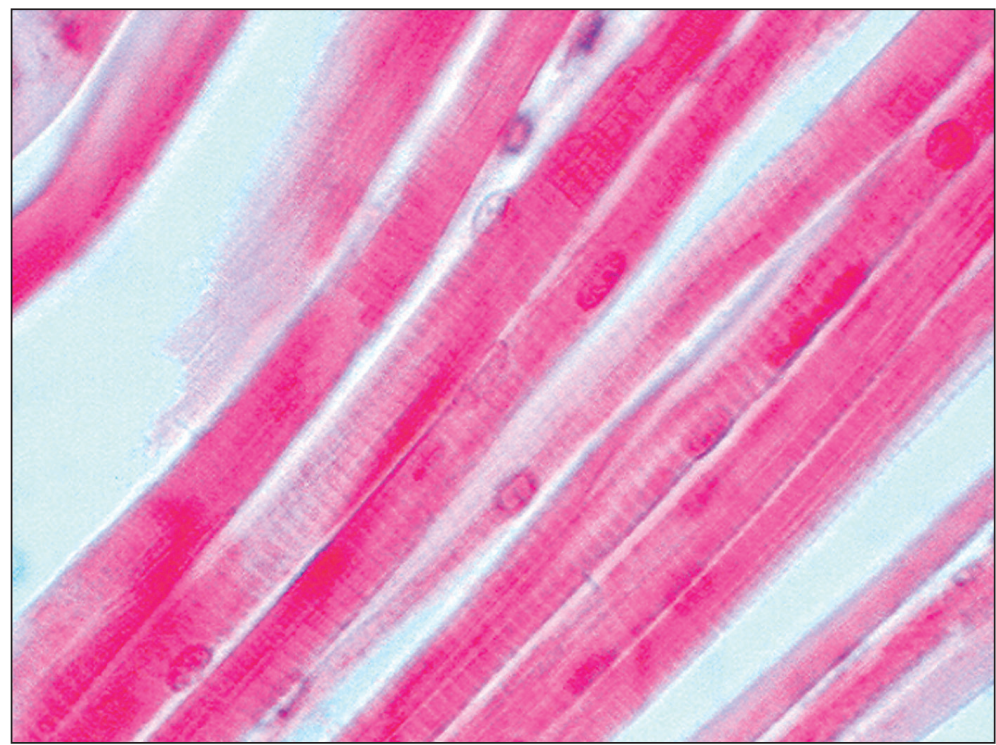

Fig. 2. Morphological changes after the exposure of $30 \mathrm{~Gy}$. HE, magnification $\times 300$ 